\title{
Perspectives on Reincarnation: Hindu, Christian, and Scientific-Editor's Introduction
}

\author{
Jeffery D. Long \\ Religion \& Asian Studies, Elizabethtown College, Elizabethtown, PA 17022, USA; longjd@etown.edu
}

Received: 24 July 2018; Accepted: 25 July 2018; Published: 27 July 2018

It has been an honor and a privilege, as well as a highly enjoyable experience, to serve as the guest editor of this special issue of Religions on the topic of reincarnation. As my own article for this issue elaborates, the topic of reincarnation is one that has fascinated me for many years, ever since a childhood tragedy led to me to reflect upon and question deeply what I had been taught on the topic of the afterlife by the religious tradition in which I was raised. That I am not alone in having a fascination with this topic is evidenced by the sheer volume of popular books and articles on the idea of rebirth produced and consumed every year. While it is a mainstream idea in those parts of the world where the Dharma traditions (Hinduism, Jainism, Buddhism, and Sikhism) predominate, recent opinion surveys have shown that as many as one in five Americans also profess a belief in some form of reincarnation. ${ }^{1}$

Scholars are not exempt from this widespread interest. Indeed, there would seem to be an upswing in scholarly interest in this topic, as the articles in this special issue indicate. This interest ranges from the historical, to the literary, to the theological and philosophical. The articles gathered here raise varying questions from equally varying perspectives on the topic of reincarnation. What do particular traditions and texts teach about reincarnation? How is reincarnation conceptualized differently in different religious and cultural contexts? These are questions of a more historical and descriptive variety. What evidence can be presented either for or against reincarnation as a really occurring phenomenon, and not merely a subject of personal belief? What philosophical or theological arguments can be marshalled either for or against the idea of reincarnation? These are questions about the veracity of claims regarding reincarnation, about whether or not there really is such a thing, and what it might mean to answer this question either affirmatively or negatively.

The articles collected here take up these questions, and more, providing a broad (though I would not say comprehensive) overview of this topic. The primary focus of the articles in this collection has been upon reincarnation as approached from either Hindu or Christian perspectives. These are two traditions whose adherents have engaged with one another on this topic with some frequency. For many Hindus, some version of the doctrine of reincarnation is axiomatic, and foundational to spiritual practice. For Christians, reincarnation has been a vexed issue, with many Christians being attracted to the idea from the earliest days of the church to the present, but with the mainstream of the tradition rejecting the idea as incompatible with foundational Christian teachings. It has thus been a natural topic of Hindu-Christian polemics. Some of these polemics have been described in articles found in this collection (e.g., the articles by Nalini Bhushan, Gérard Colas, and Usha Colas-Chauhan), while other articles in this collection are themselves contributions to this polemical literature (e.g., the article by Bradley Malkovsky, which argues from a Christian perspective, and my own, which argues from a Hindu perspective). Some of the articles collected here describe, in depth, articulations of rebirth that arise from particular Hindu texts and traditions (e.g., the articles of Gerald Larson, Jonathan

\footnotetext{
1 (Miller 2009).
} 
Edelmann, Steven Rosen, and Ithamar Theodor). One article, that of Christopher Chapple, brings the Hindu tradition into a wider dialogue with Buddhism and Jainism, while Ted Christopher's article brings Buddhism into dialogue with science.

Science (along with philosophy more broadly) is an important interlocutor in the reincarnation discourse as well, being brought to bear especially by proponents of this idea in order to establish it on a more widely agreed upon foundation than the teachings of a particular, confessional tradition, though also by critics, in order to question its veracity. Ankur Barua's article, in particular, engages the topic of the verifiability of claims about reincarnation.

Additionally, both Lee Irwin, with his extensive survey of reincarnation beliefs in America, and C. Nicholas Serra, with his close study of reincarnation in the work of William Butler Yeats, draw our attention to the fact that it is not only in Hindu and Christian contexts that reincarnation has been considered, but that there is a wider Western civilizational conversation about this topic as well.

Francis X. Clooney, who is best known for his groundbreaking (and, in many ways, ground-defining) work in comparative theology, mainly involving comparison of Hindu and Christian texts, nicely ties together this entire work with his concluding reflections.

As Clooney notes, this special issue emerged out of a panel discussion held as part of the annual meeting of DANAM (the Dharma Academy of North America) and another panel discussion that was held jointly between DANAM and the Society for Hindu-Christian Studies, both held under the auspices of the American Academy of Religion. Everyone involved, to my knowledge, in both events found the conversation to be stimulating and well worth further exploration. My hope for this special issue is that it will mark only the beginning of this deeper conversation, in which there is insight to be had for Christians, for Hindus, and for any human being who has ever wondered what, if anything, awaits each of us beyond the inevitable transition of death.

Conflicts of Interest: The author declares no conflict of interest.

\section{Reference}

Miller, Lisa. 2009. We Are All Hindus Now. Newsweek, August 15.

(C) 2018 by the author. Licensee MDPI, Basel, Switzerland. This article is an open access article distributed under the terms and conditions of the Creative Commons Attribution (CC BY) license (http://creativecommons.org/licenses/by/4.0/). 